Jurnal Info Kesehatan

Vol. 19, No. 1, June 2021, pp. 38-46

P-ISSN 0216-504X, E-ISSN 2620-536X

DOI: 10.31965/infokes.Vol19Iss1.471

Journal homepage:http://jurnal.poltekeskupang.ac.id/index.php/infokes

RES E A R C H

Open Access

\title{
Factors Associated with Providing the Basic Immunization to Infants
}

\author{
${\text { Iskandar } \operatorname{Arfan}^{1 a^{*}}, \operatorname{Mardjan}^{1 \mathrm{~b}}, \text { Yulsi Testiani }}^{{ }^{1 \mathrm{c}}}$ \\ ${ }^{1}$ Faculty of Public Health, Universitas Muhammadiyah Pontianak, Pontianak, West Kalimantan, \\ Indonesia. \\ a Email address: iskandar.arfan@unmuhpnk.ac.id \\ b Email address: mardjan.as@unmuhpnk.ac.id \\ cEmail address: arifin.lpu@gmail.com
}

Received: 5 September 2020

Revised: 22 September 2020

Accepted: 31 May 2021

\begin{abstract}
Basic immunization is the first providing immunization to acquire the immune level on the verge of protection given to baby before one year which was aimed to get a full set of basic immunization for each baby with a good indicator that is full immunization (IDL). The indicator was influenced by several independent variables such as mother's job status, education, knowledge, attitude, perception, and support from cadre and family. From total 89 villages in Lamandau district since 2015 to 2018 , there were 82 villages of Universal Child Immunization (UCI) $(92.1 \%$ ) increased by $22.78 \%$ than 2016 is $69.32 \%$. However, there was Drop Out (DO) of $2.83 \%$ from the village thathad not reached a full set of basic immunization of infants in Kujan Village. The objective of this study is to determine the factors associated with providing a full set of basic immunization of infants in Kujan village, Bulik district, Lamandau Regency, Central Kalimantan Province. The research employed cross sectional design. Data was collected from 80 mothers who had children aged 12-24 months during February 2020. The study samples was conducted with total sampling ( 80 respondents). The results of study used chi square test with levels of trust that is $95 \%$. It showed a significant relationship between education by providing a full set of basic immunization of infants with p-value $=0.000$. Meanwhile, employment status, knowledge, attitudes, family support, perceptions, support from cadres were not related to complete immunization. Therefore, based on the results of this study, it is suggested to the Lamandau Regency Government in the long term to improve the education of healthy mothers and also massive education related to the importance of immunization to increase the complete basic immunization coverage in Kujan Village.
\end{abstract}

Keywords: Basic Immunization, Education.

*Corresponding Author:

Iskandar Arfan

Faculty of Public Health, Universitas Muhammadiyah Pontianak, Pontianak, West Kalimantan, Indonesia. Email: 1skandar.arfan@unmuhpnk.ac.id

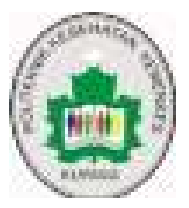

CThe Author(s) 2021. This article is distributed under the terms of the Creative Commons Attribution 4.0 International License (http://creativecommons.org/licenses/by/4.0/), which permits unrestricted use, distribution, and reproduction in any medium, provided you give appropriate credit to the original author(s) and the source, provide a link to the Creative Commons license, and indicate if changes were made. The Creative Commons Public Domain Dedication waiver (http://creativecommons.org/publicdomain/zero/1.0/) applies to the data made available in this article, unless otherwise stated. 


\section{INTRODUCTION}

Health development aims to increase awareness, willingness, and apply healthy lifestyle for people so that it can obtain the degree of quality public health as an investment for productive human resources development in social and economic. Improving the degree of public health and preserving the health status for the general public need preventive action or prevention of disease by immunization. Immunization is the best way to protect a person from a specific disease which is dangerous and deadly especially for infants and children. Based on regulation of Ministry of Health of Republic Indonesia number 12 of 2017, Immunization is an attempt to stimulate a person's immunity which is able to protect the body from the disease by immunization (PD3I) (Kementerian Kesehatan, R. I., 2017).

This immunization program is execution to prevent diseases such as tuberculosis, diphtheria, pertussis, tetanus, Hepatitis B, polio, and measles. Providing immunization was focused to early childhood because their immunity system is still weak from all kinds of diseases. The indicator of immunization program used to measure the coverage of Indonesia Sehat is the percentages of village which was reached UCI (Universal Child Immunization) (Dinas Kesehatan Provinsi Kalimantan Tengah, 2016).

Based on data from 2017, complete basic immunization indicator coverage in Central Kalimantan was $75 \%$ in 2016,bigger than the coverage in 2015 which was $64.76 \%$, but did not the target in 2016 that was set up to 90\% (Dinas Kesehatan Provinsi Kalimantan Tengah, 2017). Meanwhile, from total 89 villages in Lamandau district in 2015-2018, UCI village coverage was 82 villages $(92.1 \%)$ increased by $22.78 \%$ compared with $69.32 \%$ in 2016 .However, if observed from immunization in village level at the work area of Bulik Public Health Center, there was still drop out (DO)/were not immunized at allabout $2.83 \%$, partially immunized at village level in the work area of Bulik Public Health Center (Dinas Kesehatan Lamandau, 2018).

The results of preliminary study by interview were 10 mothers as respondents in Kujan village who had children aged 12 to 24 months,5 (50\%) of respondents said that their children did not receive a full set of basic immunization, while $5(50 \%)$ of respondents said their children received a full set of basic immunization. With description: mothers aged less than 21 were $4(40 \%)$,more than 21 were $6(60 \%), 4$ respondents $(40 \%)$ did not know about basic immunization, 6 respondents $(60 \%)$ knew about basic immunization, 3 respondents $(30 \%)$ were graduated from elementary school, 3 respondents $(30 \%)$ were graduated from junior high school and 4 respondents $(40 \%)$ were graduated from senior high school. There were 4 husbands $(40 \%)$ of respondents who banned or disagreed their children immunized, 6 husbands $(60 \%)$ of respondents agreed their children immunized, the respondents said that they have not been visited by cadre to their house for counseling who were $5(50 \%)$ and the respondents said that they had been visit their house by $5(50 \%)$. Therefore, the researcher wanted to observe the factors associated with providing a full set of basic immunization to infants. The objective of this study is to determine the factors associated with providing a full set of basic immunization to infants in Kujan village, Bulik district, Lamandau, Central Kalimantan Province.

\section{RESEARCH METHOD}

The design of the study used a cross-sectional method. Data was collected from 80 mothers who had children aged 12-24 months in Kujan village, Bulik district, 
Lamandau, Central Kalimantan Province. Secondary data was obtained by literature study of Lamandau Health Service of 2016-2018, data from Bulik Public Health Center period of 2017-2019, and primary data from respondents in Kujan village at February 2020. Primary Data was collected by interview and documentation of KMS or KIA books. Data analysis used chi-square test. Sample study was with total sampling ( 80 respondents). Ethical Approval was provided by the Ethics Committee of Muhammadiyah University No. 03/KEPK-FIKES/KET/2020.

\section{RESULTS AND DISCUSSION}

The results of the study associated with Univariate analysis were mothers' educational level which were mostly from elementary, junior and senior high school $(86.25 \%)$. Most of whom were diploma up to master $(13.75 \%)$ and worked as farmer, private employees and civil servant (45\%), and unemployment (55\%). Mother knowledge level were much less $(57.5 \%)$ and well-knowledge $(42.5 \%)$. Mothers' attitude, family and cadre support, perception and basic immunization status were part of the factors associated with providing a full set of basic immunization of infants in Kujan village, Bulik district, Lamandau, Central Kalimantan Province that can be seen in the tables below:

Table 1. Socio demographic data of respondents.

\begin{tabular}{|c|c|c|}
\hline Variable & Total (f) & Percentage (\%) \\
\hline \multicolumn{3}{|l|}{ Education } \\
\hline Higher Education & 11 & 13,75 \\
\hline Secondary Primary Education & 69 & 86,25 \\
\hline \multicolumn{3}{|l|}{ Job Status } \\
\hline Worked & 36 & 45 \\
\hline Unemployed & 44 & 55 \\
\hline \multicolumn{3}{|l|}{ Knowledge } \\
\hline Good & 34 & 42,5 \\
\hline Poor & 46 & 57,5 \\
\hline \multicolumn{3}{|l|}{ Attitude } \\
\hline Supportive & 40 & 50 \\
\hline Unsupportive & 40 & 50 \\
\hline \multicolumn{3}{|l|}{ Family Support } \\
\hline Supportive & 34 & 42,5 \\
\hline Unsupportive & 46 & 57,5 \\
\hline \multicolumn{3}{|l|}{ Perception } \\
\hline Good & 33 & 41,25 \\
\hline Poor & 47 & 58,75 \\
\hline \multicolumn{3}{|l|}{ Cadre Support } \\
\hline Supportive & 32 & 40 \\
\hline Unsupportive & 48 & 60 \\
\hline \multicolumn{3}{|l|}{ Basic Immunization Status } \\
\hline Completed & 36 & 45 \\
\hline Uncompleted & 44 & 55 \\
\hline
\end{tabular}

The results of bivariate analysis were obtained the job variable with $p$ value $=$ 0,557 , knowledge by $p$ value $=0,317$, attitude by $p$ value $=0,822$, family support by $p$ value $=0,146$, perception by $p$ value $=0,538$ and cadre support $p$ value $=0,614$. The results of bivariate analysis were showed a significant relationship between education 
with providing a full set of basic complete immunization in infants with $p$ value $=$ 0,000 .

Table 2. The variables related with giving basic complete immunization.

\begin{tabular}{|c|c|c|c|c|c|c|c|c|}
\hline \multirow{3}{*}{ Variable } & \multicolumn{4}{|c|}{ Basic Immunization } & \multirow{2}{*}{\multicolumn{2}{|c|}{ Total }} & \multirow{3}{*}{$\begin{array}{c}\text { PR } \\
(95 \% \mathrm{CI})\end{array}$} & \multirow{3}{*}{$\begin{array}{c}p \\
\text { value }\end{array}$} \\
\hline & \multicolumn{2}{|c|}{ Completed } & \multicolumn{2}{|c|}{ Uncompleted } & & & & \\
\hline & $\mathbf{n}$ & $\%$ & $\mathbf{n}$ & $\%$ & n & $\%$ & & \\
\hline \multicolumn{9}{|l|}{ Education } \\
\hline Higher Education & 11 & 100 & 0 & 0,0 & 11 & 100 & \multirow{4}{*}{$\begin{array}{c}2,760 \\
(2,018-3,774)\end{array}$} & \multirow{4}{*}{0,000} \\
\hline Secondary & & & & & & & & \\
\hline Primary & & & & & & & & \\
\hline Education & 25 & 36,2 & 44 & 63,8 & 69 & 100 & & \\
\hline \multicolumn{9}{|l|}{ Job Status } \\
\hline Worked & 18 & 50 & 18 & 50 & 36 & 100 & \multirow{3}{*}{$\begin{array}{c}1,222 \\
(0,754-1,980)\end{array}$} & \multirow{2}{*}{0,557} \\
\hline Unemployed & 18 & 40,9 & 26 & 59,1 & 44 & 100 & & \\
\hline \multicolumn{8}{|l|}{ Knowledge } & \\
\hline Good & 18 & 52,9 & 16 & 47,1 & 34 & 100 & \multirow{2}{*}{$\begin{array}{c}1,353 \\
(0,837-2,186)\end{array}$} & \multirow{2}{*}{0,317} \\
\hline Poor & 18 & 39,1 & 28 & 60,9 & 46 & 100 & & \\
\hline \multicolumn{9}{|l|}{ Attitude } \\
\hline Supportive & 17 & 42,5 & 23 & 57,5 & 40 & 100 & \multirow{2}{*}{$\begin{array}{c}0,895 \\
(0,550-1,454)\end{array}$} & \multirow{2}{*}{0,822} \\
\hline Unsupportive & 19 & 47,5 & 21 & 52,5 & 40 & 100 & & \\
\hline \multicolumn{9}{|l|}{ Family Support } \\
\hline Supportive & 19 & 55,9 & 15 & 44,1 & 34 & 100 & \multirow{2}{*}{$\begin{array}{c}1,512 \\
(0,934-2,447)\end{array}$} & \multirow{2}{*}{0,146} \\
\hline Unsupportive & 17 & 37 & 29 & 63 & 46 & 100 & & \\
\hline \multicolumn{9}{|l|}{ Perception } \\
\hline Good & 13 & 39,4 & 20 & 60,6 & 33 & 100 & \multirow{2}{*}{$\begin{array}{c}0,805 \\
(0,481-1,346)\end{array}$} & \multirow{2}{*}{0,538} \\
\hline Poor & 23 & 48,9 & 24 & 51,1 & 47 & 100 & & \\
\hline \multicolumn{9}{|l|}{ Cadre Support } \\
\hline Supportive & 16 & 50 & 16 & 50 & 32 & 100 & \multirow{2}{*}{$\begin{array}{c}1,200 \\
(0,741-1,943)\end{array}$} & \multirow{2}{*}{0,614} \\
\hline Unsupportive & 20 & 41,7 & 28 & 58.3 & 48 & 100 & & \\
\hline
\end{tabular}

The results above showed that all respondents with higher education had a full set of basic immunization (100\%) compared to middle-education respondents (elementary, junior high school), just reached (36.2\%). Based on the statistical test result by $p$ value $=0.000(<\alpha=0.05)$,it can be concluded that there was significant relationship between education with providing a full set of basic immunization in infants.

Based on job status above, it can be identified that mother who worked had been full-immunized status $(50 \%)$ a few more than mother who did not work by fullimmunized status (40.9\%). According to the statistical test result of $p$-value 0.557 ( $>\alpha$ $=0.05)$,it means that there was no significant relationship between mother's job status with providing a full set of basic immunization in infants.

Based on mother education, it can be seen that mother with good knowledge had more a full set of basic immunization $(52.9 \%)$ bigger than poor knowledge $(39.1 \%)$, and the statistic test result of $p$-value $0.317(>\alpha=0.05)$.It means that there was no relationship between knowledge with providing a full set of basic immunization in infants. 
Meanwhile, the respondents support had fewer a full set of basic immunization (42.5\%) than unsupported mother (47.5\%). Based on the statistic test result by $p$ value $=0.822(>\alpha=0.05)$, it can be concluded that there was no significant relationship between mothers' support with providing a full set of basic immunization in infants.

The factor of family support had a full set of basic immunization $(55.9 \%)$ than the unsupported family (37\%). The results of analysis data were obtained by $p$ value $=$ $0.146(>\alpha=0.05)$. It can be concluded that there was no significant relationship between the family support with providing a full set of basic immunization in infants.

The respondents with good perception had more a full set of basic immunization status $(39.4 \%)$ less than the respondent with poor perception $(48.9 \%)$. The result of statistical test was obtained by $p$ value $=0.538(>\alpha=0.05)$. It can be concluded that there was no significant relationship between mothers' perception with providing a full set ofbasic immunization in infants.

Mother claimed that cadre support by a full set of basic immunization status $(50 \%)$, while the unsupported cadres by a full set of basic immunization status about (41.7\%). The result of the statistical test was obtained by $p$ value $=0.614(>\alpha=0.05)$.It can be concluded that there was no significant relationship between cadre support with providing a full set of basic immunization in infants.

Based on the results of this study, In terms of the factors associated with providing a full set of basic immunization in Kujan village, there was some independent variables in this study which had no relationship with basic immunization of infants, such as: job status, knowledge, mother attitude, perception, cadre and family support.

The results of this study, in statistically showing, there was significant relationship between educational level with providing a full set of basic immunization in infants by $p$ value $=0.000$ in Kujan village. This result as studied by Suhaid \& Faranita, (2018) explained that educational level was related to a full set of basic immunization of infants in Alamendah village, Rancabali, Bandung. Furthermore, the results of study by Maiwada, et. al., (2019) revealed that there was a significant relationship between mothers' educational status with providing a full set of basic immunization to children in Kebbi Nigeria, and it was the main factor that contributed to the attitude of mothers for providing immunization to their child. Similarly, the results of study by Girmay \& Dadi, (2019) in Ethiopia explained that the low educational is very influential and adverse for achieving the immunization status of infants, and the results of study by Maharani \& Kuroda, (2018) stated that improving the quality of education is the most important factor in component quality of health service in general and immunizations. However, different from the study previously, in the result of the study by Hafid, et. al., (2016) revealed that there was no influence between mothers' educational level with full immunized of infants by a $p$ value $=0.177$.

In this study, mother's job status had no significant relationship with mother's job after the statistical test, as with previous study that mother's job had no statistical influence to full immunized in infants with $p$ value $=0.404$ by Hafid, et. al., (2016). As the study by Triana, (2016) explained that there was no meaningful relationship between parent's job with providing full immunized of infants in Kuranji district, Padang, 2015,thus, there was no spread of the respondent's job status by $p$ value $=0.66$ $(>0.05)$. Meanwhile, different from the study by Suhaid \& Faranita, (2018), it is stated that there was relationship of job factor with full immunization in infant.

The result of the statistical test in this study showed that the respondents with poor knowledge did not have a significant relationship with providing a full set of basic immunization in infants, as study by Rahmi \& Husna, (2018) stated that mother 
knowledge has no influence with full immunization of infants by $p$ value (0.05). The same results of study were conducted by Rahmawati \& Wahjuni, (2014) and Risnawati (2014), which revealed that the level of mother knowledge has no influence with basic immunization status of infants.

Different research from Emilya, et. al., (2014) stated that there was a relationship between knowledge with full immunization of infants in Lambung village, Bukit Padang. It is supported by the results of study by Suhaid \& Faranita, (2018), which stated that there was a relationship between knowledge with full immunization status of infant in Alamendah village, Rancabali, Bandung. Furthermore, the results of the study Sari, et. al., (2016) added that there was also a significant relationship between mothers' knowledge about basic immunization with full immunization of infants in the work area of Bendo Health Center, Magetan. The same research by Girmay \& Dadi, (2019) in Ethiopia indicating that the level of mother knowledge with a poor life was very influential in full immunization of children aged 12-23 months in difficult reachable area in Ethiopia.

The results of this analysis revealed that unsupported respondents to the basic immunization in infants is higher than the respondents support, thus, there was no significant relationship between mothers' attitude with providing a full set of basic immunization in Kujan village. Inversely, proportional to the results of the study by Hudhah \& Hidajah, (2017) and Saifuddin, (2013), it has the same statement that there was an influence of mother's attitude to her rejection and readiness due to personal experience and influence from other which was important, because of cultural and emotional factor that influenced the full immunization of infants. The study by Emilya, et. al., (2014) explained that there was a relationship between mother attitudes with providing a full set of basic immunization to infants in Lambung, Bukit Kota Padang. Similarly, the study of Maiwada, et. al., (2019), stated that there was a significant relationship between mothers' attitude with full immunization to children in the state of Kebbi Nigeria.

Based on the result of statistical test for the family support variable, it can be concluded that there was no significant relationship between family support variable with full immunization of infants. The results were not in line with the study by Ritonga, et. al., (2015). It explained that there was an emotional support relationship of mother compliance toper form basic immunization to their child. The emotional support should be provided by the family such as empathy, caring and attention to other. Hence, it becomes motivated to immunize their children.

Similarly, the results of previous study by Rahmawati \& Wahjuni, (2014), in line with this study explained that there was relationship between family support with full immunization of infants by $p$ value $=0.000(<0.05)$. The results of this study was also in line with the results of statistical tests on previous study by Hafid, et. al., (2016), from the result of analysis and statistical test byp-value $=0.000$, it indicates that there was a significant influenced between family support with full immunization of infants in Konang and Geger Health Center.

Based on the results of this study, the analysis result indicated that mothers' perception was not a significant relationship with providing full basic immunization of infants. The result of this study is in line with the study by Ahmad, et. al, (2017) in 
Malaysia which explained that the children did not receive a full primary immunization at 12 months, most girls were from urban areas, the mothers did not trust that the vaccine can prevent the spread of disease and get treatment in private facilities. Hence, this study identified the challenges and gaps to make sure high immunization coverage in Malaysia in reducing the number of child illness and death because there are many mothers with low perception.

The results of this study also showed the statistical test. There was no significant relationship between cadre supports with full immunization of infants. It is in line with the results of previous study by Septianingtyas, (2018) which revealed that there was no relationship between the implementation of cadre role with full basic immunization in infants. Different with the research by Septianingtyas, (2018), the results of data analysis employing the logistic regression test showed $p$ value $=0.013(p<0.05)$, which means that there was a significant influence from cadre support with full basic immunization in the work area of Jelbuk and Klatakan Health Center, Jember.

The study result of Meleko, et. al., (2017), in Mizan Aman city, Bench Maji Zone, Southwest Ethiopia, Immunization remains one of the most important and costeffective public health interventions to reduce child mortality and morbidity. Globally, it is estimated to avert between 2 and 3 million deaths each year. In Ethiopia, immunization coverage rates have stagnated and remained very low for many years. The bigger proportion occurred in Sub-Saharan Africa, about 4.4 million. It is caused by inadequate immunization coverage due to the infrastructure which is not optimal, especially for routine vaccination that identified as the primary factors of less vaccinations.

From the results of the research by Noh, et. al., (2018) in Pakistan, it was discovered that the immunization level coverage among children aged 0-23 months in Pakistan has increased since EPI program was initiated by WHO in 1978, but still lower than the countries with low- and middle-income level as the goal of WHO and UNICEF. The low vaccination coverage and delay to immunize have aroused the loss of immunity causing the disease epidemic that can be prevented by vaccines in infants who had not been vaccinated in Pakistan.

Based on study by Girmay \& Dadi, (2019) in Ethiopia, it is indicated that the full immunization coverage of the district was higher than the national and regional coverage, but lower than World Health Organization target. The mileage to public health center, mothers who did not have self-checking during ANC (Ante Natal Care) and a very poor life also affect to infants immunization status. Hence, it is expected to relevant parties strengthening the outreach of immunization service, cooperating actively with the local community-based on health services to increase the number of children vaccinate.

Thus, the research concluded that the family support is not only from husband but also from other family members such as grandmother, grandfather, parents and siblings. The successful of basic complete immunization in infants is not only from one factor but also from other important factors, because the success of the coverage or basic immunization target depends also from a government program so that all infants in Indonesia reach the status of IDL (basic complete immunization). Hence, there is a 
cooperation between medical officers like midwife or nurse with Posyandu (Maternal \& Child Health Centre) cadres in the local village area by approaching people and family. Thus, it will be easy to tell information about the benefits of immunization for healthy xinfant. To reach WHO standards of immunization coverage and also to improve the quality of health and education, policymakers have to design programs for further socialization about immunizations to baby's mother and their family who have a low education (Maharani \& Kuroda, 2018).

\section{CONCLUSION}

There is a significant relationship between the education variable and complete basic immunization for infants. Based on the results of this study, it is suggested to the Lamandau Regency Government in the long term to improve maternal education and also massive education related to the importance of immunization to increase the complete basic immunization coverage in Kujan Village.

\section{REFERENCES}

Ahmad, N. A., Jahis, R., Kuay, L. K., Jamaluddin, R., \& Aris, T. (2017). Primary immunization among children in malaysia: Reasons for incomplete vaccination. Journal of Vaccines \& Vaccination, 8(3), 1-8. doi: https://doi.org/10.4172/2157-7560.1000358

Dinas Kesehatan Lamandau. (2018). Profil Dinas Kesehatan Lamandau Tahun 2018. Nanga Bulik: Dinas Kesehatan Lamandau.

Dinas Kesehatan Provinsi Kalimantan Tengah. (2016). Profil Dinas Kesehatan Provinsi Kalimantan Tengah Tahun 2016. Palangkaraya: Dinas Kesehatan Provinsi Kalimantan Tengah.

Dinas Kesehatan Provinsi Kalimantan Tengah. (2017). Profil Dinas Kesehatan Provinsi Kalimantan Tengah Tahun 2017. Palangkaraya: Dinas Kesehatan Provinsi Kalimantan Tengah.

Emilya, S., Lestari, Y., \& Asterina, A. (2017). Hubungan Pengetahuan dan Sikap Ibu Balita terhadap Tindakan Imunisasi Dasar Lengkap di Kelurahan Lambung Bukit Kota Padang Tahun 2014. Jurnal Kesehatan Andalas, 6(2), 386-390. doi: https://doi.org/10.25077/jka.v6i2.709

Girmay, A., \& Dadi, A. F. (2019). Full immunization coverage and associated factors among children aged 12-23 months in a hard-to-reach areas of Ethiopia. International journal of pediatrics, 2019, ID 1924941, 8 pages, doi: https://doi.org/10.1155/2019/1924941

Hafid, W., Martini, S., \& Devy, S. R. (2016). Faktor determinan status imunisasi dasar lengkap pada bayi di Puskesmas Konang dan Geger. Jurnal Wiyata: Penelitian Sains dan Kesehatan, 3(1), 38-45.

Hudhah, M., \& Hidajah, A. (2017). Perilaku Ibu Dalam Imunisasi Dasar Lengkap Di Puskesmas Gayam Kabupaten Sumenep. Jurnal Promkes: The Indonesian Journal of Health Promotion and Health Education, 5(2), 167-180. doi: http://dx.doi.org/10.20473/jpk.V5.I2.2017.167-180

Kementerian Kesehatan, R. I. (2017). Data and Informasi: Profil Kesehatan Indonesia. Jakarta: Kementerian Kesehatan Republik Indonesia. 
Maharani, A., \& Kuroda, Y. (2018). Determinants of immunization status among 12-to 23-month-old children in Indonesia (2008-2013): a multilevel analysis. BMC Public Health, 18, (288), 1-11. doi: https://doi.org/10.1186/s12889-018-5193-3

Maiwada, A. A., Dahiru, S., \& Onwuka, G. I. (2019). A Survey on Attitude of Mothers towards Immunization of Their Children in Nigeria (A Case Study of Zuru Metropolis). The International Journal of Engineering and Science (IJES), 8 (11) $31-38$.

Meleko, A., Geremew, M., \& Birhanu, F. (2017). Assessment of child immunization coverage and associated factors with full vaccination among children aged 1223 months at Mizan Aman town, bench Maji zone, Southwest Ethiopia. International journal of pediatrics, 2017, ID 7976587, 11 pages. doi: https://doi.org/10.1155/2017/7976587

Noh, J. W., Kim, Y. M., Akram, N., Yoo, K. B., Park, J., Cheon, J., ... \& Stekelenburg, J. (2018). Factors affecting complete and timely childhood immunization coverage in Sindh, Pakistan; A secondary analysis of cross-sectional survey data. PloS one, 13(10), e0206766. doi: https://doi.org/10.1371/journal.pone.0206766

Rahmawati, A., \& Wahjuni, C. (2014). Factors Affecting Completeness Basic Immunization Village District of North Krembangan. Jurnal Berkala Epidemiologi, 2(1), 59-70. doi: http://dx.doi.org/10.20473/jbe.V2I12014.59-70

Rahmi, N., \& Husna, A. (2018). Faktor yang Mempengaruhi Kelengkapan Imunisasi Dasar pada Bayi di Wilayah Kerja Puskesmas Peukan Bada Kabupaten Aceh Besar. Journal of Healthcare Technology and Medicine, 4(2), 209-222. doi: https://doi.org/10.33143/jhtm.v4i2.222

Risnawati, D. (2014). Pengaruh Pengetahuan, Pendidikan, Pendapatan, dan Budaya Ibu Terhadap Kelengkapan Imunisasi Dasar Lengkap di Kelurahan Pacarkembang. Skripsi. Surabaya: Faculty of Public Health, Universitas Airlangga.

Ritonga, M., Syarifah, M. S., \& Tukiman, M. K. M. (2015). Hubungan Antara Dukungan Keluarga Terhadap Kepatuhan Ibu Melaksanakan Imunisasi Dasar Pada Anak Di Desa Tigabolon Kecamatan Sidamanik Kabupaten Simalungun Tahun 2014. Kebijakan, Promosi Kesehatan dan Biostatistika, 1(2).

Saifuddin, A. (2013). Sikap manusia teori dan pengukurannya. Yogyakarta: Pustaka Pelajar Offset.

Sari, D. N. I., Basuki, S. W., Triastuti, N. J. (2016). Hubungan pengetahuan ibu tentang imunisasi dasar dengan kelengkapan imunisasi dasar bayi di wilayah kerja puskesmas bendo Kabupaten Magetan. Biomedika, 8 (2), 6-12, doi: https://doi.org/10.23917/biomedika.v8i2.2910

Septianingtyas, W. R., \& Soesetijo, F. A., Yani, R. W. E. (2018). Pengaruh Dukungan Kader dalam Imunisasi Dasar Lengkap di wilayah kerja Puskesmas Jelbuk dan Klatakan, Kabupaten Jember. Multidisciplinary Journal, 1(1), 21-24. doi: https://doi.org/10.19184/multijournal.v1i1.8593

Suhaid, D. N., \& Faranita, F. (2018). Factors Associated with Basic Immunization Status of Infants. SEAJOM: The Southeast Asia Journal of Midwifery, 4(1), 3239. doi: https://doi.org/10.36749/seajom.v4i1.26

Triana, V. (2016). Faktor yang berhubungan dengan pemberian imunisasi dasar lengkap pada bayi tahun 2015. Jurnal kesehatan masyarakat Andalas, 10(2), 123-135. doi: https://doi.org/10.24893/jkma.v10i2.196 